\title{
HUBUNGAN PENGETAHUAN TENTANG METODE KONTRASEPSI DENGAN SIKAP TERHADAP PEMILIHAN METODE KONTRASEPSI PADA AKSEPTOR KONTRASEPSI WANITA
}

\author{
${ }^{1)}$ Lasiah Susanti, ${ }^{2)}$ Vanny Nurdelima Habsi \\ ${ }^{1,2}$ Departemen Ilmu Kesehatan Masyarakat, Fakultas Kedokteran dan Ilmu Kesehatan, Universitas Abdurrab \\ ${ }^{1,2)}$ Jl. Riau Ujung No 73 Pekanbaru - Riau - Indonesia \\ E-mail : ${ }^{1)}$ lasiahsusanti@gmail.com, ${ }^{2)}$ vannynurdelimahabsi22@gmail.com
}

\begin{abstract}
Kata Kunci:
akseptor KB wanita, kontrasepsi,

pengetahuan, puskesmas pekanbaru, sikap
\end{abstract}

Keywords:

attitude,

knowledge, primary health center, women's contraceptive acceptor

\section{Info Artikel}

Tanggal dikirim: 15-9-2020

Tanggal direvisi: $22-9-2020$

Tanggal diterima:29-9-2020

DOI Artikel:

10.36341/cmj.v3i3.1435

Attribution-NonCommercial 4.0

$\underline{\text { International. Some rights reserved }}$

\section{ABSTRAK}

Keluarga Berencana (KB) merupakan program pertama yang ditetapkan oleh pemerintah Indonesia sebagai salah satu metode untuk menekan pertumbuhan penduduk di Indonesia sejak tahun 1970. Badan Kependudukan dan Keluarga Berencana Nasional (BKKBN) membentuk program pembangunan berkelanjutan yaitu Kependudukan, Keluarga Berencana, dan Pembangunan Keluarga (KKBPK) yang setara dengan program tingkat internasional Sustainable Development Goals (SDGs). Peserta KB aktif Provinsi Riau dari tahun 2017-2018 selalu berada pada urutan ke-8 terendah dari 34 provinsi di Indonesia dengan metode terbanyak berupa non Metode Kontrasepsi Jangka Panjang (non-MKJP). Salah satu penyebabnya yaitu rendahnya pengetahuan masyarakat terkait dengan metode kontrasepsi. Pengetahuan dan sikap merupakan landasan dalam membentuk suatu perilaku yang sesuai kondisi bagi akseptor kontrasepsi. Tujuan penelitian ini adalah mengetahui hubungan pengetahuan tentang metode kontrasepsi dengan sikap tentang pemilihan metode kontrasepsi pada akseptor kontrasepsi wanita di Puskesmas wilayah Kota Pekanbaru. Penelitian ini menggunakan desain studi observasional analitik, dengan rancangan penelitian cross sectional. Penelitian ini dilakukan pada 12 Puskesmas di Kota Pekanbaru. Teknik pengambilan sampel dilakukan dengan cara stratified random sampling dengan besar sampel 400 orang dan diuji secara statistik menggunakan uji korelasi Spearman. Hasil analisis korelasi Spearman's rho menunjukkan terdapat hubungan yang signifikan antara pengetahuan dengan sikap ( $p_{\text {value }}=0,027$ ) dengan nilai koefisien korelasi 0,097.

\section{ABSTRACT}

Family planning is the first program established by the Indonesian government as one of the methods to suppress population growth in Indonesia since 1970. Badan Kependudukan dan Keluarga Berencana Nasional (BKKBN) established a sustainable development program namely Kependudukan, Keluarga Berencana dan Pembangunan Keluarga (KKBPK) which is equivalent to the international level program Sustainable Development Goals (SDGs). Participants of Riau province are using active contraception from 2017-2018 always ranks 8th lowest out of 34 provinces in Indonesia with the most methods in the form of non-longterm contraception methods (non-MKJP). One of the reason is low of society knowledge related to contraceptive methods. Knowledge and attitude are foundation in forming a behavior that is suitable with conditions for contraceptive acceptor.The purpose of this research was to know the relationship of knowledge about contraceptive methods with attitudes about the selection of contraceptive methods in women's contraceptive acceptors in primary health center region of Pekanbaru city.The method of this research used analytic observational study design, with a cross sectional study design. This research was conducted at 12 primary health centers region of Pekanbaru city. The sampling technique is done by stratified random sampling with a sample size of 400 people and statistically tested using the Spearman correlation test. The result of spearman 's rho correlation analysis indicate there is a significant relationship between knowledge and attitude (pvalue $=0.027$ ) with a correlation coefficient value of 0.097 . 


\section{PENDAHULUAN}

Berdasarkan sensus penduduk pada tahun 2010 hingga tahun 2016, jumlah penduduk di Indonesia mengalami peningkatan [9]. Dengan semakin meningkatnya jumlah kependudukan Indonesia, program Keluarga Berencana (KB) ini ditetapkan sebagai salah satu metode untuk menekan pertumbuhan peduduk di Indonesia sesuai dengan program Kependudukan, Keluarga Berencana, dan Pembangunan Keluarga (KKBPK) yang diambil dari salah satu program pembangunan berkelanjutan tingkat internasional Sustainable Development Goals (SDGs) yaitu kehidupan sehat dan sejahtera [1,5,24].

Prevalensi pengguna metode kontrasepsi di dunia, Indonesia merupakan negara yang ke-10 terendah dari 71 negara di dunia dengan pengguna metode kontrasepsi terbanyak berupa non Metode Kontrasepsi Jangka Panjang (non-MKJP)[22]. Peserta KB aktif Provinsi Riau dari tahun 2017-2018 selalu berada pada urutan ke-8 terendah [8]. Tingginya minat akseptor menggunakan metode non-MKJP ini salah satunya disebabkan rendahnya pengetahuan masyarakat tentang metode kontrasepsi MKJP [5,6]. Dengan adanya pengetahuan tentang metode kontrasepsi dan sikap terhdap pemilihan metode kontrasepsi akan membentuk suatu perilaku yang sesuai dengan kondisi akseptor dalam penggunaan metode kontrasepsi [11].

Tujuan dari penelitian ini adalah untuk mengetahui hubungan pengetahuan tentang metode kontrasepsi dengan sikap tentang pemilihan metode kontrasepsi pada akseptor kontrasepsi wanita di Puskesmas wilayah Kota Pekanbaru. Penelitian ini memberikan manfaat pada akseptor kontrasepsi wanita, puskesmas yang terkait, institusi pendidikan dan bagi peneliti yang berlandasan untuk menerapkan tujuan penelitian pada penelitian ini.

Hasil penelitian Thapa et al tentang pengetahuan metode kontrasepsi dan sikap terhadap pemilihan metode kontrasepsi menegaskan bahwa jika pengetahuan ditingkatkan maka sikap untuk menerima metode kontrasepsi akan lebih baik dan jika ada peningkatan pengetahuan dan sikap yang baik, maka dalam penerapan pemilihan metode kontrasepsi pada akhirnya akan lebih baik lagi [20]. Hasil penelitian yang dilakukan oleh Goncalves et al menarik kesimpulan bahwa pengetahuan merupakan faktor dominan dalam penentuan sikap dan perilaku pemilihan metode kontrasepsi [3]. Selain itu, penelitian yang dilakukan pada akseptor KB wanita usia subur di Kelurahan Bandarharjo Kota Semarang menarik kesimpulan bahwa faktor umur wanita usia subur, pengetahuan, dan sikap wanita usia subur mempunyai hubungan yang signifikan terhadap pemilihan jenis kontrasepsi non IUD (non-MKJP) pada akseptor KB wanita usia subur [16]. Di sisi lain, penelitian yang dilakukan oleh Putri memiliki hasil bahwa salah satu faktor yang berhubungan dengan pemilihan alat kontrasepsi adalah tingkat pengetahuan ibu terhadap metode kontrasepsi [13].

\section{METODE}

Penelitian ini menggunakan desain studi observasional analitik, dengan rancangan penelitian cross sectional. Penelitian ini dilakukan pada 12 Puskesmas di Kota Pekanbaru. Teknik pengambilan sampel dilakukan dengan cara stratified random sampling dengan besar sampel 400 responden. Data yang didapat diuji secara statistik menggunakan uji korelasi Spearman.

\section{HASIL DAN PEMBAHASAN}

Hasil uji korelasi Spearman diperoleh nilai p-value sebesar 0,027 menunjukkan bahwa terdapat hubungan yang signifikan antara pengetahuan tentang metode kontrasepsi dengan sikap terhadap pemilihan metode kontrasepsi pada akseptor kontrasepsi wanita di Puskesmas wilayah Kota Pekanbaru. Penelitian ini sejalan dengan penelitian yang di lakukan oleh Thapa et al yang menyatakan bahwa pengetahuan tentang kontrasepsi dengan sikap pemilihan metode kontrasepsi memiliki hubungan yang signifikan dengan $\mathrm{p}$ value $<0,01$ [20]. Penelitian yang dilakukan oleh Putri et al mendapatkan hasil bahwa satusatunya faktor yang berhubungan dengan pemilihan alat kontrasepsi adalah tingkat pengetahuan ibu dengan p-value 0,01 [13]. 
Penelitian ini juga sejalan dengan penelitian yang dilakukan oleh Saragih et al mendapatkan hasil analisis bivariat diperoleh usia (p-value $0,045)$, pengetahuan ( $\mathrm{p}$-value 0,049 ) dan sikap (p-value 0,001) memiliki hubungan yang signifikan terhadap pemilihan jenis kontrasepsi pada akseptor kontrasepsi wanita [16]. Nilai koefisien korelasi pada penelitian ini sebesar 0,097 yang artinya korelasi tersebut memiliki kekuatan korelasi sangat lemah. Arah korelasi dalam penelitian ini adalah positif yang artinya semakin tinggi skor pengetahuan tentang metode kontrasepsi yang dimiliki oleh responden, maka semakin tinggi skor sikap responden terhadap pemilihan metode kontrasepsi dan begitu juga sebaliknya.

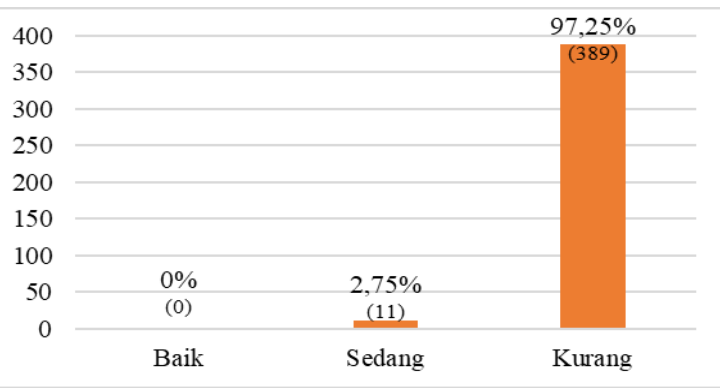

Gambar 1. Karakteristik Tingkat Pengetahuan Akseptor Kontrasepsi Wanita

Berdasarkan hasil penelitian terkait karakteristik pengetahuan akseptor kontrasepsi wanita menyatakan bahwa akseptor kontrasepsi wanita memiliki skor tingkat pengetahuan yang kurang tentang metode kontrasepsi yang sesuai akseptor kontrasepsi gunakan (Gambar 1). Sementara itu, dilihat dari hasil skor sikap dalam pemilihan metode kontrasepsi menyatakan bahwa mayoritas akseptor kontrasepsi wanita memiliki skor sikap yang kurang dalam pemilihan metode kontrasepsi (Gambar 2). Hal ini dapat disimpulkan bahwa skor pengetahuan akseptor kontrasepsi wanita yaitu dalam kategori kurang sehingga sikap dalam pemilihan metode kontrasepsi wanita juga memiliki skor dalam kategori kurang.

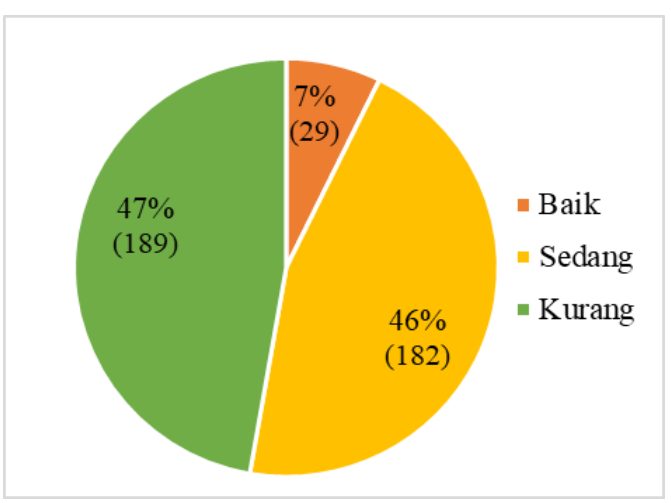

\section{Gambar 2. Karakteristik Sikap Dalam Pemilihan Metode Kontrasepsi}

Penelitian ini sejalan dengan penelitian yang dilakukan oleh Pattypeilohy yang menyatakan bahwa mayoritas responden memiliki tingkat pengetahuan dalam memilih metode kontrasepsi yang sesuai masih kurang [12]. Hal ini dikarenakan kurangnya pengalaman menjadi akseptor kontrasepsi (akseptor kontrasepsi baru), kurang terpaparnya terhadap informasi tentang $\mathrm{KB}$, dan tidak adanya motivasi dari dalam diri akseptor sendiri untuk ingin tahu terkait dengan metode kontrasepsi yang sesuai digunakannya. Selain itu, dari segi skor sikap yang kurang sejalan dengan penelitian sebelumnya yang memiliki hasil pengetahuan dan sikap masih dalam kategori kurang. Hal ini karena responden pada penelitian tersebut memiliki keyakinan bahwa seseorang yang menggunakan alat $\mathrm{KB}$ akan bisa terkena infertilitas dan sebagian besar dari mereka memiliki sikap yang tidak menguntungkan terhadap program Keluarga Berencana.

Menurut teori Bloom, ranah kognitif merupakan faktor yang begitu penting dalam membentuk tindakan suatu individu [11]. Faktor predisposisi sebagai salah satu faktor yang mempengaruhi tindakan (perilaku) kesehatan akseptor. Pengetahuan dan sikap terhadap tradisi dan kepercayaan, sistem nilai yang dianut masyarakat, tingkat pendidikan, tingkat sosial dan ekonomi merupakan faktor predisposisi menurut teori Green [14]. Pengetahuan tentang metode kontrasepsi pada akseptor kontrasepsi wanita memiliki hubungan yang erat dengan sikap dalam pemilihan metode kontrasepsi. Adanya 
pengetahuan tentang metode kontrasepsi akan membentuk sikap dalam pemilihan metode kontrasepsi akseptor kontrasepsi wanita [11].

Menurut Thapa et al, pendidikan, pekerjaan, dan penghasilan keluarga per bulan memiliki keterkaitan terhadap terbentuknya pengetahuan tentang metode kontrasepsi [20]. Pendidikan merupakan salah satu faktor eksternal yang dapat mempengaruhi akseptor dalam bertindak. Hasil penelitian ini menunjukkan bahwa responden yang memiliki tingkat pendidikan terbanyak yaitu Sekolah Menengah Atas/Kejuruan (SMA/SMK) (Gambar 3). Hal ini sejalan dengan penelitian yang dilakukan oleh Sweya dan Goncalves et al yang menyatakan bahwa karakteristik responden dari segi tingkat pendidikan terakhir terbanyak dalam pemilihan metode kontrasepsi adalah Sekolah Menengah $[3,19]$. Menurut Kusumaningrum (2013) cit Saragih et al, responden yang memiliki tingkat pendidikan tinggi akan lebih memudahkan responden dalam menerima dan mengaplikasikan suatu informasi dalam kehidupan, khususnya terkait dengan pemilihan penggunaan kontrasepsi [16].

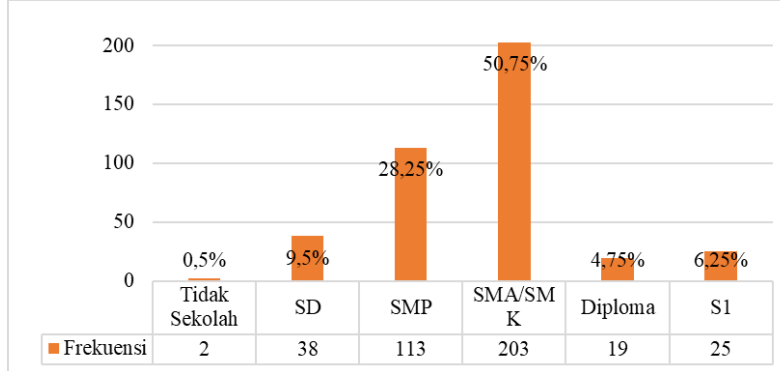

\section{Gambar 3. Karakteristik Akseptor Kontrasepsi Wanita Berdasarkan Pendidikan Terakhir}

Pekerjaan tidak kalah pentingnya yang harus dibahas dalam penelitian ini. Fakta yang terjadi pada masyarakat saat ini yakni semakin banyak wanita berperan dalam membantu suami dari segi mencari tambahan penghasilan atas dasar memenuhi kebutuhan rumah tangga ataupun mengurus kebutuhan rumah tangga, di mana seorang wanita semakin cakap memerankan dirinya di tengah-tengah keluarga dan masyarakat. Hal ini menjadi dampak pada cara berpikir masyarakat yang mulai mengalami perkembangan sesuai dengan kemajuan ilmu pengetahuan dan teknologi, yakni alat komunikasi untuk mendapatkan suatu informasi, alat transportasi, bahkan arus globalisasi yang semakin cepat. Oleh karena itu, pekerjaan merupakan salah satu faktor yang berpengaruh terhadap fenomena pekerjaan wanita pasangan usia subur untuk mencari nafkah adalah mengenai tingkat pengambilan keputusan dalam keluarganya. Pekerjaan merupakan faktor yang berperan dalam terbentuknya pengetahuan tentang metode kontrasepsi dan sikap dalam pemilihan metode kontrasepsi [17]. Mayoritas dari jenis pekerjaan akseptor kontrasepsi wanita pada penelitian ini yaitu mengurus rumah tangga (Gambar 4). Hal ini sejalan dengan penelitian Dawra et al pada tahun 2020 yang menyatakan bahwa mayoritas terbanyak dari jenis pekerjaan akseptor kontrasepsi wanita yaitu mengurus rumah tangga [2].

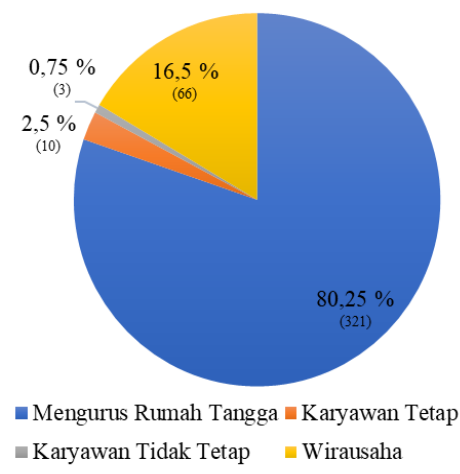

\section{Gambar 4 Karakteristik Akseptor Kontrasepsi Wanita Berdasarkan Pekerjaan}

Usia, pendidikan, umur anak terakhir dan jarak ke fasilitas kesehatan terdekat memiliki hubungan erat tebentuknya sikap terhadap pemilihan metode kontrasepsi [20]. Usia seseorang juga dapat mempengaruhi dalam terbentuknya pengetahuan, di mana semakin lanjut usia seseorang maka kemungkinan semakin meningkat pengetahuan dan pengalaman yang dimilikinya. Usia akan mempengaruhi terhadap daya tangkap dan pola pikir seseorang, di mana semakin bertambah usia akan semakin berkembang pula daya tangkap 
dan pola pikirnya sehingga pengetahuan yang diperoleh semakin membaik [11]. Namun, usia bukan satu-satunya faktor yang mempengaruhi terbentuknya pengetahuan dan sikap yang baik pada diri akseptor kontrasepsi wanita. Selanjutnya, wanita pada Pasangan Usia Subur dengan usia yang lebih dari 35 tahun sangat diperlukan dalam penggunaan kontrasepsi, karena pada usia tersebut berguna untuk mencegah kehamilan pada resiko tinggi [4]. Mayoritas kelompok usia akseptor kontrasepsi wanita pada penelitian ini yaitu 36 sampai 40 tahun (Gambar 5). Hal ini sejalan dengan penelitian yang dilakukan oleh Putri yang menyatakan bahwa mayoritas kelompok usia akseptor kontrasepsi MKJP dan non- MKJP berada pada usia lebih dari 35 tahun [13].

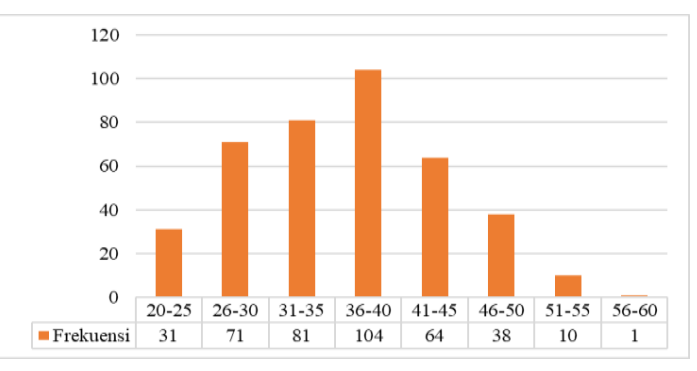

\section{Gambar 5. Karakteristik Usia Akseptor Kontrasepsi Wanita}

Akseptor kontrasepsi wanita meyakini apa yang telah ia alami pada dirinya. Akseptor kontrasepsi yang memiliki pengalaman terhadap kontrasepsi sebelumnya yang telah ia gunakan menimbulkan ketidak sesuaian pada dirinya. Dari hasil penelitian didapatkan bahwa mayoritas akseptor pada penelitian ini merupakan akseptor kontrasepsi wanita lama (Gambar 6). Akseptor kontrasepsi wanita lama kemungkinan memiliki pengalaman lebih dalam mengetahui dan memilih metode kontrasepsi. Namun faktanya tingkat pengetahuan dan sikap akseptor masih dalam kategori kurang. Kurangnya pengetahuan tentang metode kontrasepsi dan sikap dalam pemilihan metode kontrasepsi ini perlu dibentuk oleh akseptor kontrasepsi wanita menjadi lebih baik lagi dalam bentuk konseling yang baik. Konseling memiliki tujuan untuk membantu seseorang mengenali kondisinya saat ini, masalah yang sedang dihadapi dan menentukan jalan keluar untuk mengatasi masalah tersebut [18].

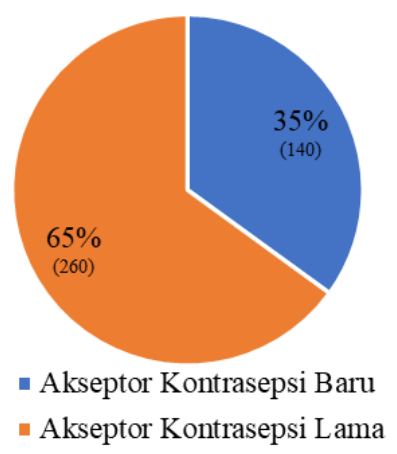

Gambar 6. Gambaran Akseptor Kontrasepsi Wanita Baru dan Lama

Fasilitas kesehatan merupakan salah satu faktor yang mempengaruhi dalam terbentuknya pengetahuan dan sikap akseptor kontrasepsi. Fasilitas kesehatan merupakan instrumen dalam ruang lingkup kotrasepsi. Akseptor kontasepsi wanita dapat membentuk pengetahuan tentang kontrasepsi secara rasional melalui kegiatan konseling oleh konselor di fasilitas kesehatan [21]. Konseling merupakan upaya dalam membantu seseorang untuk bisa meraih pengetahuan, pemahaman yang lebih baik sehingga teratasi masalah yang sedang di arungi dalam bentuk metode wawancara [23]. Pada penelitian ini didapatkan bahwa mayoritas akseptor kontrasepsi wanita telah melakukan konseling. Dengan adanya konseling diharapkan akseptor kontrasepsi wanita memiliki tingkat pengetahuan dan sikap dalam pemilihan metode kontrasepsi yang baik. Namun, kenyataannya pengetahuan tentang metode kontrasepsi dan sikap dalam pemilihan metode kontrasepsi yang sesuai dengan kondisi akseptor masih dalam kategori kurang walaupun akseptor kontrasepsi wanita telah melakukan konseling. Hal ini peneliti beramsumsi bahwa konseling bukan satusatunya faktor yang mempengaruhi dalam terbentuknya pengetahuan tentang metode kontrasepsi dan sikap dalam pemilihan metode kontrasepsi yang baik sesuai dengan kondisi akseptor kontrasepsi.

Pengetahuan akseptor kontrasepsi wanita dipengaruhi oleh beberapa faktor yaitu faktor internal yang berasal dari dalam diri 
Collaborative Medical Journal (CMJ)

Vol.3 No.2, Mei 2020

akseptor kontrasepsi berupa pengalaman, umur dan pendidikan terakhir akseptor, sedangkan faktor eksternal yang berasal dari luar individu akseptor kontrasepsi berupa pengaruh kebudayaan dan media massa [3]. Tingkat pengetahuan dipengaruhi beberapa faktor yaitu sosial ekonomi, kultur (budaya dan agama), pendidikan, pengalaman, terkait informasi yang didapatkan, umur, intelegensi dan lingkungan [10]. Pendidikan, penghasilan keluarga / bulan dan status pernikahan merupakan faktor yang memiliki hubungan dalam terbentuknya pengetahuan tentang metode kontrasepsi, sedangkan usia dan tingkat pengetahuan merupakan faktor yang memiliki hubungan dalam terbentuknya sikap pemilihan metode kontrasepsi [15].

\section{KESIMPULAN}

1. Terdapat hubungan yang signifikan (sig. 0,027 ) antara pengetahuan tentang metode kontrasepsi dengan sikap tentang pemilihan metode kontrasepsi.

2. Mayoritas akseptor kontrasepsi wanita pada tingkat pengetahuan dan sikap dalam kategori kurang.

\section{DAFTAR PUSTAKA}

[1] Badan Kependudukan dan Keluarga Berencana Nasional. Rencana Strategis Badan Kependudukan dan Keluarga Berencana Nasional. Jakarta: Renstra BKKBN, 2015.

[2] Dawra S, Goyal S, Gupta M C. Knowledge, Attitude and Practices of Contraceptive Methods in Women of Reproductive Age Group in an Urban District of Haryana. Rohtak: Society for Scientific Research under a CC BY-NC 4.0 International License, 2020.

[3] Goncalves M J, Suariyani N.L.P, dan Suyadhi N.T. Hubungan Pengetahuan dan Sikap dengan Pemakaian Alat Kontrasepsi pada PUS di Puskesmas Comoro Dili Timor Leste. Timor Leste: Public Health and Preventive Medicine Archive, 2014.

[4] Huda A N, Widagdo L, Dan Widjarnako B. Faktor-Faktor Yang Berhubungan Dengan Perilaku Penggunaan Alat
P-ISSN : 2615-0328

E-ISSN : 2615-6741

Kontrasepsi Pada Wanita Usia Subur Di Puskesmas Jombang-Kota Tangerang Selatan. Semarang: Jurnal Kesehatan Masyarakat Universitas Diponegoro, 2016.

[5] Kementrian Kesehatan Republik Indonesia. Pusat Data dan Informasi Situasi dan Analisis Keluarga Berencana. Jakarta Selatan: Kementrian Kesehatan RI, 2014.

[6] Kementrian Kesehatan Republik Indonesia. Profil Kesehatan Indonesia Tahun 2017. Jakarta: Kementrian Kesehatan RI, 2018a.

[7] Kementrian Kesehatan Republik Indonesia. Alat Bantu Pengambilan Keputusan berKB Edisi Revisi 2018. Jakarta: Kementrian Kesehatan RI, 2018b.

[8] Kementrian Kesehatan Republik Indonesia. Data dan Informasi Profil Kesehatan Indonesia Tahun 2018. Jakarta: Kementrian Kesehatan RI, 2019.

[9] Kementrian Pekerjaan Umum. Buku informasi statistik 2017, Pusat Data dan Teknologi Informasi (Pusdatin). Jakarta: Kementrian Pekerjaan Umum dan Perumahan Rakyat Sekretariat Jendral Pusat Data dan Teknologi Informasi (Pusdatin), 2017.

[10] Mulyaningsih S dan Sariyati S. Analisis Tingkat Pengetahuan Akseptor KB Tentang Alat Kontrasepsi di Puskesmas Sedayu I Tahun 2014. Yogyakarta: Jurnal Ners dan Kebidanan Indonesia, 2014.

[11] Notoadmojo, S. Promosi Kesehatan dan Perilaku Kesehatan. Jakarta: Rineka Cipta, 2014.

[12] Pattypeilohy A. Studi Tingkat Pengetahuan Ibu dalam Memilih Metode Kontrasepsi yang Sesuai di Kelurahan Fontein Tahun 2018. Kupang: Program Studi Kebidanan Sekolah Tinggi Ilmu Kesehatan Citra Husada Mandiri, 2018.

[13] Putri, N. P. D., Pradnyaparamitha, D. Dan Ani, L. S. Hubungan Karakteristik, Tingkat Pengetahuan dan Sikap Ibu dengan Pemilihan Kontrasepsi pada Pasangan Usia Subur di Kecamatan Sidemen Kabupaten Karangasem Bali. Bali: E-Journal Medika, 2019. 
Collaborative Medical Journal (CMJ)

Vol.3 No.2, Mei 2020

[14] Priyoto. Teori Sikap dan Perilaku Dalam Kesehatan. Yogyakarta: Nuha Medika, 2018.

[15] Saelim J, Santibenchakul S, dan Jaisamrarn U. Comparison of the knowledge, attitudes toward, and practices of contraception between Thai Muslim women living in Bangkok and those living in the southernmost provinces of Thailand. Bangkok: Asian Biomedicine, 2016.

[16] Saragih I M, Suharto, dan Nugraheni A. Faktor-Faktor yang Berhubungan dengan Pemilihan Penggunaan Metode Kontrasepsi Non-IUD pada Akseptor KB Wanita Usia Subur di Kelurahan Bandarharjo Semarang Utara. Semarang: Jurnal Kedokteran Diponegoro, 2018.

[17] Setiadi Dan Iswanto L. Pengambilan Keputusan Penggunaan Alat Kontrasepsi Istri Dalam Keluarga. Yogyakarta: Universitas Gajah Mada, 2015.

[18] Sulistiyaningsih $\mathrm{S} \quad \mathrm{H}$. Efektivitas Konseling KB Terhadap Pengetahuan Dan Sikap Pus Dalam Pemilihan Kontrasepsi Intra Uterine Device (IUD). Pati: Akademi Kebidanan Bakti Utama Pati, 2017.

[19] Sweya M N, Msuya S E, Mahande M J, Manongi M. Contraceptive Knowledge, Sexual Behavior, And Factors Associated With Contraceptive Use Among Female Undergraduate University Students In Kilimanjaro Region In Tanzania. Moshi: Adolescent Health, Medicine and Therapeutics, 2018.

[20] Thapa P, Pokharel N, dan Shrestha M. Knowledge, Attitude and Practices of Contraception Among the Married Women of Reproductive Age Group in Selected Wards of Dharan SubMetropolitan City. Nepal: Journal of Contraceptive Studies, 2018.

[21] Triyanto L Dan Indriani D. Faktor Yang Mempengaruhi Penggunaan Jenis Metode Kontrasepsi Jangka Panjang (MKJP) Pada Wanita Menikah Usia Subur Di Provinsi Jawa Timur. Surabaya: The Indonesian Journal of Public Health Universitas Airlangga, 2018.

[22] United Nations. Trends in
P-ISSN : 2615-0328

E-ISSN : 2615-6741

Contraceptive Use Worldwide 2015. New York: Departement of Economic and Social Affairs Population Division, 2015.

[23] Utami F dan Indreswari S A. Konseling Pemilihan Alat Kontrasepsi Pada Wanita Pasangan Usia Subur Di Puskesmas Mangkang Semarang. Semarang: Jurnal Visikes, 2013.

[24] World Health Statistics. Monitoring Health For The SDGs Sustainable Development Goals. Switzerland: Monitoring Health for the SDGs, Sustainable Development Goals. Geneva: World Health Organization, 2018. 